\title{
DETEKSI KUALITAS AIR SUMUR MASYARAKAT AKIBAT PENUMPUKAN LIMBAH DI SEKITAR TEMPAT PEMBUANGAN AKHIR MENGGUNAKAN LASER PHOTO-ACOUSTICS SPECTROSCOPY DI GAMPONG JAWA KECAMATAN KUTARAJA BANDA ACEH
}

\author{
(Detection of Water Quality of Wells of Communities Due to Waste Accumulation Around \\ Final Disposal Site Using Photoacoustics Laser in Gampong Jawa Kecamatan Kuta Raja \\ Banda Aceh)
}

\author{
Khairul Abdi Ruslana ${ }^{1}$, Ichwana ${ }^{1}$, Agus Arip Munawar ${ }^{1 *}$ \\ ${ }^{1}$ Program Studi Teknik Pertanian Fakultas Pertanian Universitas Syiah Kuala
}

\begin{abstract}
Abstrak. Dalam menguji kualitas air di Laboratorium biasanya memerlukan biaya yang mahal dan waktu yang lama. Laser Photo-Acoustics Spectroscopy adalah salah satu metode terbaru untuk uji cepat kualitas air. Tujuan dari penelitian ini adalah untuk menguji keakuratan laser fotoakustik sebagai metode baru yang cepat, efektif, dan efisien dalam mendeteksi kualitas air sumur masyarakat akibat penumpukan limbah di sekitar Tempat Pembuangan Akhir di Gampong Jawa Kecamatan Kuta Raja Banda Aceh dengan menggunakan Laser Fotoakustik. Hasil penelitian ini menunjukkan panjang gelombang relevan untuk prediksi kualitas air sumur menggunakan rentang panjang gelombang $4000-10000 \mathrm{~cm}^{-1}$ dimana parameter suhu, kekeruhan, TSS, $\mathrm{pH}, \mathrm{DO}, \mathrm{BOD}-5$ dan nitrat $\left(\mathrm{NO}_{3}-\right)$ berada pada rentang panjang gelombang tersebut. Metode koreksi spektrum yang paling baik digunakan untuk prediksi suhu, kekeruhan, TSS dan DO ialah metode koreksi cutting edge filtering, prediksi pH dan $\mathrm{NO}_{3}$ - paling baik menggunakan data raw spektrum sementara prediksi BOD-5 paling baik mengggunakan metode koreksi peak normalization. Pada data raw spektrum nilai r berkisar pada $0.8349537-0.9926958$, nilai RMSEC berkisar pada 0.0387916 - 3.7519751, nilai $\mathrm{R}^{2} 0.6971$ - 0.9854453 , nilai RPD 1.942375418 6.949700451. Pada metode koreksi peak normalization nilai $\mathrm{r}$ berkisar pada $0.8151091-0.9910417$, nilai RMSEC 0.0447571 - 5.7055745, nilai $\mathrm{R}^{2} 0.65995$ - 0.98216, nilai RPD 1.833200928 - 6.668034607. Pada metode koreksi cutting edge filtering nilai $\mathrm{r}$ berkisar $0.882751-0.9980677$, nilai RMSEC $0.0410234-1.9323903$, nilai $\mathrm{R}^{2} 0.76829$ - 0.9961392, nilai RPD $2.22078388-17.20520953$.
\end{abstract}

Kata Kunci : kualitas air, panjang gelombang relevan, metode koreksi.

Abstract. In testing the quality of water in the Laboratory usually requires a high cost and a long time. The Photo-Acoustics Spectroscopy Laser is one of the newest methods for rapid water quality testing. The purpose of this research is to test the accuracy of photoacoustic laser as a new method that quickly, effectively and efficiently in detecting the quality of well water of society due to the accumulation of waste around the Final Disposal Site in Gampong Jawa, Kuta Raja Raja sub-district by using Laser Fotoakustik. The results of this study show the relevant Wavelength for well water quality prediction using the $4000-10000 \mathrm{~cm}-1$ wavelength range where the temperature, turbidity, TSS, $p H, D O, B O D-5$ and nitrate (NO3 -) parameters are in the wavelength range. The best spectral correction methods used for prediction of temperature, turbidity, TSS and DO are cutting edge filtering correction methods, $\mathrm{pH}$ and $\mathrm{NO} 3$ predictions-best using raw spectrum data while BOD-5 predictions best use peak normalization correction methods. In raw data spectrum $r$ value ranges from 0.8349537 - 0.9926958 , RMSEC value ranges from 0.0387916 - 3.7519751, value $R 20.6971$ - 0.9854453 , RPD value 1.942375418 6.949700451. In peak correction method normalization $r$ value ranges from $0.8151091-0.9910417$, RMSEC value 0.0447571 - 5.7055745, value R2 0.65995 - 0.98216, RPD value 1.833200928 - 6.668034607. In correction method of cutting edge filtering $r$ value ranges from $0.882751-0.9980677$, RMSEC value $0.0410234-1.9323903$, value R2 0.76829 - 0.9961392, RPD value 2.22078388 - 17.20520953.

Keywords : water quality, relevant wavelengths, correction method.

\section{PENDAHULUAN}

Tempat Pembuangan Akhir (TPA) biasanya menjadi sumber utama pencemaran air di sumur maupun di sungai. TPA sebagai sumber pencemar air menghasilkan berbagai polutan yang dapat mencemarkan air. Polutan tersebut contohnya limbah yang mengandung bibit penyakit, limbah yang membutuhkan oksigen yang tinggi sehingga sulit untuk terurai, bahan tidak sedimen serta bahan yang mengandung radioaktif yang tinggi. 
Biasanya untuk menduga kandungan air dilakukan uji laboratorium dimana dalam pengujian tersebut dibutuhkan waktu yang sangat lama, dan melibatkan bahan kimia, serta membutuhkan biaya yang sangat mahal. Pada saat ini banyak sekali usaha yang dilakukan untuk uji cepat kualitas air. Salah satu metode yang sedang digunakan untuk mendeteksi kandungan pangan dan pertanian adalah menggunakan alat Laser Photo-Acoustics Spectroscopy (LPAS). Teknologi LPAS (Laser PhotoAcoustics Spectroscopy) merupakan teknik atau metode yang menggunakan radiasi sinar laser untuk menganalisa komposisi kimia dari bahan organik. Informasi kandungan kimia ini didapatkan berdasarkan reaksi dari bahan biologik setelah diberi radiasi sinar laser (Munawar et al, 2016).

Adapun permasalahan yang dapat dirumuskan pada penelitian ini ialah bagaimana cara untuk menentukan kadar kualitas air secara cepat, efektif dan efisien tanpa melibatkan bahan kimia tambahan. Tujuan dari penelitian ini ialah untuk menguji keakuratan Laser Photo-Acoustic Spectroscopy sebagai metode baru yang cepat, efektif, dan efisien dalam mendeteksi kualitas air sumur masyarakat akibat penumpukan limbah di sekitar Tempat Pembuangan Akhir di Gampong Jawa Kecamatan Kuta Raja Banda Aceh dengan menggunakan Laser Photo-Acoustic Spectroscopy.

\section{BAHAN DAN METODE}

\section{Tempat dan Waktu Penelitian}

Penelitian ini akan dilaksanakan pada bulan November sampai Desember 2017. Tempat pelaksanaan penelitian di Laboratorium Instrumentasi dan Energi, Program Studi Teknik Pertanian, Fakultas Pertanian, Universitas Syiah Kuala, Banda Aceh. Analisis sampel air dilaksanakan di Laboratorium Balai Riset dan Standardisasi Industri (BARISTAND) Banda Aceh.

\section{Alat dan Bahan}

Alat dan bahan yang digunakan pada penelitian ini adalah Global Positioning System (GPS), self developed LPAS single beam, sensor Piezoelectric, Mikrokontroller, unscrambler software ${ }^{\circledR} X$ version 10.1, dan ArcGIS 10.3. Bahan yang digunakan pada penelitian ini adalah air sumur pantau 1 (SP1), sumur pantau 2 (SP2), sumur pantau 3 (SP3), sumur bor (SB), sumur masyarakat 1 (SM1), sumur masyarakat 2 (SM2), sumur masyarakat 3 (SM3), dan sumur masyarakat 4 (SM4).

\section{Prosedur Penelitian}

Pengambilan sampel air dilakukan dengan menggunakan metode purposive sampling. Metode ini merupakan teknik pengambilan sampel secara sengaja sehingga titik pengambilan sampel akan ditentukan sendiri oleh peneliti (Ulwan, 2014). Kemudian peneliti memilih 8 titik lokasi pengambilan sampel air yakni 4 titik pada lingkup TPA dan 4 titik diluar lingkup TPA. Penelitian ini dilakukan dengan mengambil sampel air pada 8 titik dimana 4 sampel diambil pada 4 titik di lingkup TPA yakni sumur pantau 1 (SP1), sumur pantau 2 (SP2), sumur pantau 3 (SP3) dan sumur bor (SB) serta 4 sampel pada 4 titik diluar TPA yakni sumur masyarakat 1 (SM1) beradius 300 $\mathrm{m}$ dari TPA, sumur masyarakat 2 (SM2) beradius $500 \mathrm{~m}$ dari TPA, sumur masyarakat 3 (SM3) beradius $1000 \mathrm{~m}$ dari TPA dan sumur masyarakat 4 (SM4) beradius $300 \mathrm{~m}$ dari TPA. Kemudian dilakukan uji parameter fisika dan parameter kimia pada masing - masing sampel air di laboratorium BARISTAND Banda Aceh. Selanjutnya dilakukan tahap pengujian laser fotoakustik terhadap masing - masing sampel air.

\section{Akuisisi Spektrum LPAS Untuk Air}

Spektrum LPAS untuk air didapatkan dengan menggunakan instrumen self developed LPAS dengan konfigurasi alur kerja alat (workflow) dibangun dengan menggunakan self modified Thermo Integration $\mathbb{R}$. Spektrum transmisi LPAS diakuisisi dengan metode pulsed excitation dengan 
wavenumber $4000-10000 \mathrm{~cm}^{-1}$. File spektrum akan disimpan dalam bentuk file *.jdx dan *.csv untuk dianalisa lebih lanjut.

\section{Pengukuran Parameter Kualitas Air}

\subsubsection{Parameter Fisik}

Untuk parameter fisik, parameter yang diukur ialah total padatan terlarut/TSS (Total Suspended Solid).

\subsubsection{Parameter Kimia}

Untuk parameter kimia, beberapa senyawa yang akan diukur diantaranya ialah derajat keasaman $(\mathrm{pH})$, oksigen terlarut/DO (Dissolved Oxygen), BOD (Biochemical Oxygen Demand) dan Nitrat $\left(\mathrm{NO}_{3^{-}}\right)$.

\section{Metode Uji Laboratorium}

Pengukuran kualitas air juga dilakukan di laboratorium Balai Riset dan Standardisasi Industri (BARISTAND) Banda Aceh. Adapun beberapa metode - metode yang digunakan untuk mengukur parameter kualitas air di laboratorium tersebut terdapat pada Tabel 1.

Tabel 1. Pengukuran parameter kualitas air, metode dan peralatan yang dipakai

\begin{tabular}{|c|c|c|c|c|}
\hline No. & Jenis Pengukuran & Satuan & Metode yang digunakan & Alat \\
\hline & Fisika & & & \\
\hline 1. & Suhu Air & ${ }^{\circ} \mathrm{C}$ & Pemuaian Raksa & Termometer \\
\hline 2. & Kekeruhan & Skala NTU & Turbidimetri & Turbidimeter \\
\hline \multirow[t]{2}{*}{3.} & TSS & $\mathrm{mg} / \mathrm{l}$ & Gravimetri & Konduktimeter \\
\hline & $\underline{\text { Kimia }}$ & & & \\
\hline 4. & $\mathrm{pH}$ & - & Potensiometri & $\mathrm{pH}$-meter \\
\hline 5. & Nitrat $\left(\mathrm{NO}_{3}-\right)$ & $\mathrm{mg} / \mathrm{l}$ & Spektrofotometri & Spektrofotometer \\
\hline 6. & DO & $\mathrm{mg} / \mathrm{l}$ & Potensiometri & DO-meter \\
\hline .7 & BOD & $\mathrm{mg} / \mathrm{l}$ & Titrimetri & Winkler \\
\hline
\end{tabular}

Sumber : BARISTAND Banda Aceh, 2017

\section{Analisa Data Spektrum}

Data spektrum yang telah didapatkan dari hasil akuisisi kemudian dianalisa terlebih dahulu sebelum digunakan untuk mengkaji sifat karakteristik sifat intensitas elektromagnetik (IE) dan membangun model prediksi kualitas air. Analisa data spektrum yang akan dilakukan meliputi: outlier removal. Data spektrum awal diinspeksi dengan memprojeksikan data spektrum dengan metode partial least square regression (PLSR). Selanjutnya dilakukan perbaikan data spektrum. Perbaikan tersebut dilakukan dengan tujuan untuk menghilangkan noise pada spektrum akibat interferensi dan scattering photon, serta pengaruh over-heat. Metode koreksi yang akan digunakanuntuk memperbaiki data spektrum yang belum dikoreksi dalam prosedur ini adalah peak normalization dan cutting edge filtering.

\section{Model Prediksi Kualitas Air, Validasi dan Evaluasi Model}

Kualitas air diprediksi dengan cara membangun model persamaan matematik berdasarkan data sifat elektro-optik air (variabel X) dan data kualitas air hasil pengukuran di laboratorium (variabel Y). Model prediksi dibangun dengan menggunakan metode: partial least square (PLS). Secara skematis, model prediksi ini diilustrasikan seperti pada Gambar 1. 


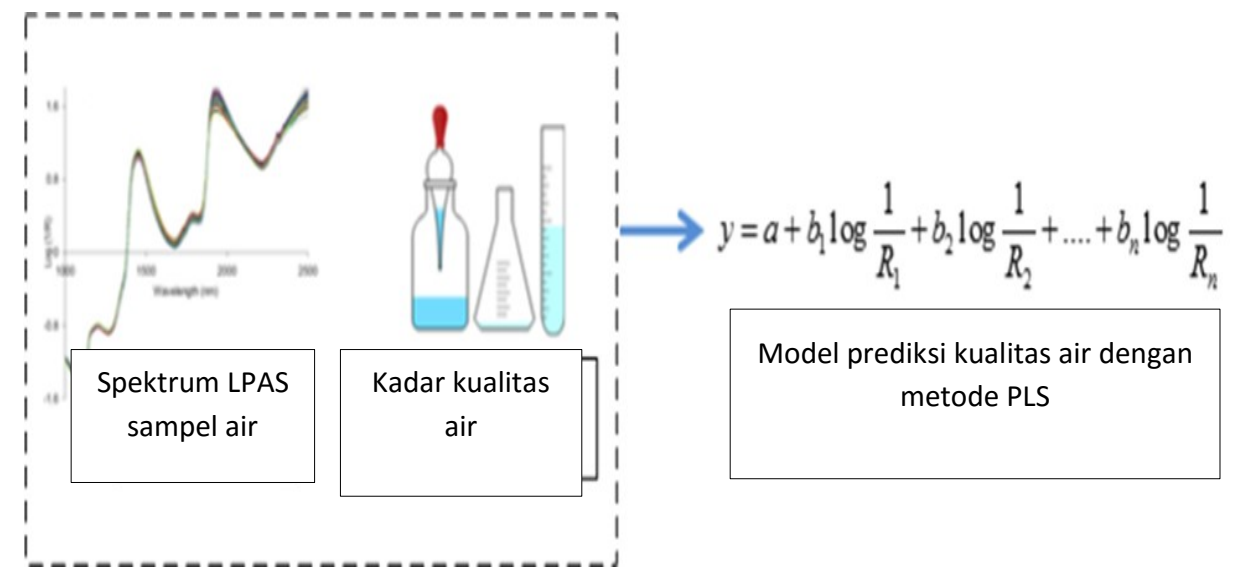

Gambar 4. Skematik Pembangunan Model Prediksi Kualitas Air Berbasis LPAS (Munawar et al, 2016)

Keakuratan model dalam memprediksi akan divalidasi dan dievaluasi dengan metode validasi silang (cross validation). Evaluasi keakuratan dan kehandalan model dievaluasi dengan melihat parameter statistik yang meliputi; koefisien korelasi (r), root mean square error (RMSE), residual predictive deviation index (RPD), dan jumlah latent variable (LV). Kualitas air hasil prediksi kemudian dibandingkan dengan hasil pengukuran standar di laboratorium dan model terbaik dipilih berdasarkan akurasi dan kehandalannya. Secara lebih ringkas, prosedur penelitian dan metode yang digunakan disusun dalam bentuk diagram alir (flowchart) seperti pada Gambar 5.

Parameter statistika yang biasa digunakan untuk mengevaluasi model yang dihasilkan adalah Nilai Error (SEC), Nilai Koefisien Korelasi (r), Nilai Koefisien Determinasi $\left(\mathrm{R}^{2}\right)$, dan RPD dihitung dengan persamaan sesuai Tabel 2. Dan Interpretasi nilai koefisien determinasi dapat dilihat pada Tabel 3 dan nilai RPD pada Tabel 4.

Tabel 2. Persamaan Statistika Untuk Evaluasi Model Kalibrasi

\begin{tabular}{ll}
\hline \multicolumn{1}{c}{ Persamaan } & Rekomendasi \\
\hline $\operatorname{SEC}(\%)=\sqrt{\frac{1}{n-1} \sum\left(X_{n}-Y_{n}\right)^{z}}$ & $\begin{array}{l}\text { Sekecil mungkin. Rasio antara SEC dan SEP } \\
\text { mendekati 100. }\end{array}$ \\
$\mathrm{r}=\frac{\sum\left(X_{n}-\bar{X}_{n}\right)\left(Y_{n}-\bar{Y}_{n}\right)}{\sqrt{\left(X_{n}-\bar{X}_{n}\right)^{z}\left(Y_{n}-\bar{Y}_{n}\right)^{z}}}$ & Sebaiknya mendekati 1 diatas 0,90 sudah tinggi. \\
$R^{2}=\left(\frac{\sum\left(X_{n}-\bar{X}_{n}\right)\left(Y_{n}-\bar{Y}_{n}\right)}{\sqrt{\left(X_{n}-\bar{X}_{n}\right)^{z}\left(Y_{n}-\bar{Y}_{n}\right)^{z}}}\right)$ & $\geq 0,5$ \\
$\operatorname{RPD}=\frac{\mathrm{SD}}{R M S E C V}$ & $\geq 1,5$ \\
Sumber : Ulva, 2016 &
\end{tabular}

Tabel 3. Interpretasi Nilai Koefisien Determinasi $\left(\mathrm{R}^{2}\right)$

\begin{tabular}{ll}
\hline \multicolumn{1}{c}{ Nilai Koefisien Determinasi } & \multicolumn{1}{c}{ Interpretasi } \\
\hline $0,50-0,65$ & Lebih dari $50 \%$ variabel Y dipengaruhi oleh variabel \\
& $\mathrm{X}$ \\
$0,66-0,81$ & Mendekati prediksi kuantitatif
\end{tabular}

Deteksi Kualitas Air Sumur Masyarakat Akibat Penumpukan Limbah di Sekitar 
$0,82-0,90 \quad$ Prediksi yang baik

$>0.91 \quad$ Prediksi yang sangat baik

Sumber :Karoui et al, 2006

Tabel 4. Interpretasi Nilai RPD

Nilai RPD Interpretasi

\begin{tabular}{ll}
\hline $1,5-1,9$ & Prediksi masih kasar (sufficient performance) \\
$2-3$ & Prediksi yang baik (good model performance) \\
$>3$ & Prediksi yang sangat baik (very good performance)
\end{tabular}

Sumber : Nicolai et al, 2007

Evaluasi keakuratan dan kehandalan model dievaluasi dengan melihat parameter statistik yang meliputi: koefisien kolerasi (r), koefesien determinasi $\left(\mathrm{R}^{2}\right)$, residual predictive deviation (RPD) index, root mean square error cross validation (RMSECV), root mean square error calibration (RMSEC), latent variable (LV), dan RMSE . Model RMSEC, RMSECV, RPD, dan LV. Model yang bagus memiliki nilai $r$ dan $\mathrm{R}^{2}$ yang tinggi, RMSEC yang rendah, RPD $>1.5$ jumlah latent variable $<9$; RMSEC, RPD, dan RMSE dicari dengan persamaan tertentu (Florez, 2009 ; Jha, 2006 ; Nicolai, 2007 ; Zulfahrizal, 2015).

\section{HASIL DAN PEMBAHASAN}

\section{Deskripsi Wilayah Penelitian}

Pengambilan sampel air diambil dilingkup Tempat Pembuangan Akhir (TPA) Gampong Jawa Kecamatan Kuta Raja Banda Aceh dan luar TPA. Gampong Jawa memiliki luas 150 Ha dengan 555 jumlah rumah tangga dan penduduk berjumlah 2762 orang. Desa ini terletak pada ketinggian $1 \mathrm{~m}$ di atas permukaan laut. Lokasi TPA ini dipilih karena masih terdapat pengaruh limbah TPA terhadap kualitas air pada sumur masyarakat yang ada disekitar TPA tersebut sehingga perlu dilakukan pengujian secara cepat terhadap kualitas air pada lingkup TPA dan diluar lingkup TPA.

TPA Gampong Jawa ini menampung seluruh sampah yang ada di Kota Banda Aceh. TPA Gampong Jawa ini pertama kali dibangun pada tahun 1994 dengan luas $12 \mathrm{Ha}$. Secara geografis TPA Gampong Jawa ini berada di antara $112^{\circ} 37^{\prime} 58^{\prime \prime}$ BT-112 $38^{\prime} 01^{\prime \prime}$ BT dan $7^{\circ} 13^{\prime} 02^{\prime \prime}$ LS-7 ${ }^{\circ} 13$ '19” LS. TPA ini memiliki 3 zona yakni zona A, zona B dan zona C. Zona A yang sudah digunakan sebanyak $2 \mathrm{Ha}$ yang sudah digunakan system sanitary landfill, zona B sebanyak 1 Ha untuk tempat pembuangan yang belum di tutup, dan untuk zona $\mathrm{C}$ sebanyak 2 Ha yang akan digunakan sebagai prasarana TPA Gampong Jawa. TPA ini memiliki 3 sumur pantau dan 1 sumur bor yang digunakan untuk penelitian kualitas air pada TPA tersebut. 


\section{Hasil Uji Kualitas Air Oleh BARISTAND}

Tabel 5. Hasil analisa Laboratorium BARISTAND Banda Aceh untuk pengujian kualitas air pada masing - masing sampel.

\begin{tabular}{|c|c|c|c|c|c|c|c|c|c|}
\hline \multirow[t]{2}{*}{ No. } & \multirow[t]{2}{*}{ Sampel } & \multicolumn{7}{|c|}{ Hasil Uji Parameter } & \multirow[t]{2}{*}{ Kelas } \\
\hline & & Suhu & Kekeruhan & TSS & $\mathrm{pH}$ & BOD-5 & DO & $\mathrm{NO}_{3}-$ & \\
\hline 1. & SP1 & $26.6^{\circ} \mathrm{C}$ & $6.89 \mathrm{NTU}$ & $\begin{array}{l}41.25 \\
\mathrm{mg} / \mathrm{L}\end{array}$ & 7.28 & $\begin{array}{c}2.5 \\
\mathrm{mg} / \mathrm{L}\end{array}$ & $\begin{array}{r}1.18 \\
\mathrm{mg} / \mathrm{L}\end{array}$ & $\begin{array}{c}1.5 \\
\mathrm{mg} / \mathrm{L}\end{array}$ & Kelas IV \\
\hline 2. & $\mathrm{SP} 2$ & $26.5^{\circ} \mathrm{C}$ & $0.615 \mathrm{NTU}$ & $\begin{array}{c}60 \\
\mathrm{mg} / \mathrm{L}\end{array}$ & 7.39 & $\begin{array}{c}0.8 \\
\mathrm{mg} / \mathrm{L}\end{array}$ & $\begin{array}{r}6.19 \\
\mathrm{mg} / \mathrm{L}\end{array}$ & $\begin{array}{c}1.6 \\
\mathrm{mg} / \mathrm{L}\end{array}$ & $\begin{array}{c}\text { Kelas III dan } \\
\text { IV }\end{array}$ \\
\hline 3. & SP3 & $26.5^{\circ} \mathrm{C}$ & $10.35 \mathrm{NTU}$ & $\begin{array}{l}31.25 \\
\mathrm{mg} / \mathrm{L}\end{array}$ & 7.25 & $2 \mathrm{mg} / \mathrm{L}$ & $\begin{array}{r}3.02 \\
\mathrm{mg} / \mathrm{L}\end{array}$ & $\begin{array}{c}1.7 \\
\mathrm{mg} / \mathrm{L}\end{array}$ & $\begin{array}{c}\text { Kelas III dan } \\
\text { IV }\end{array}$ \\
\hline 4. & SB & $26.3^{\circ} \mathrm{C}$ & $0.325 \mathrm{NTU}$ & $\begin{array}{l}18.75 \\
\mathrm{mg} / \mathrm{L}\end{array}$ & 7.94 & $0.9 \mathrm{mg} / \mathrm{L}$ & $\begin{array}{c}1.9 \\
\mathrm{mg} / \mathrm{L}\end{array}$ & $\begin{array}{c}1.9 \\
\mathrm{mg} / \mathrm{L}\end{array}$ & Kelas IV \\
\hline 5. & SM1 & $26.4{ }^{\circ} \mathrm{C}$ & $25.25 \mathrm{NTU}$ & $\begin{array}{l}111.5 \\
\mathrm{mg} / \mathrm{L}\end{array}$ & 7.41 & $2.2 \mathrm{mg} / \mathrm{L}$ & $\begin{array}{l}3.38 \\
\mathrm{mg} / \mathrm{L}\end{array}$ & $\begin{array}{c}2.2 \\
\mathrm{mg} / \mathrm{L}\end{array}$ & $\begin{array}{c}\text { Kelas III dan } \\
\text { IV }\end{array}$ \\
\hline 6. & SM2 & $26.4^{\circ} \mathrm{C}$ & $9.525 \mathrm{NTU}$ & $\begin{array}{c}25 \\
\mathrm{mg} / \mathrm{L}\end{array}$ & 7.87 & $1.1 \mathrm{mg} / \mathrm{L}$ & $\begin{array}{r}0.22 \\
\mathrm{mg} / \mathrm{L}\end{array}$ & $\begin{array}{c}1.7 \\
\mathrm{mg} / \mathrm{L}\end{array}$ & Kelas IV \\
\hline 7. & SM3 & $26.5^{\circ} \mathrm{C}$ & $0.68 \mathrm{NTU}$ & $\begin{array}{l}13.17 \\
\mathrm{mg} / \mathrm{L}\end{array}$ & 7.51 & $0.8 \mathrm{mg} / \mathrm{L}$ & $\begin{array}{r}5.57 \\
\mathrm{mg} / \mathrm{L}\end{array}$ & $\begin{array}{c}1.8 \\
\mathrm{mg} / \mathrm{L}\end{array}$ & $\begin{array}{c}\text { Kelas II, III } \\
\text { dan IV }\end{array}$ \\
\hline 8. & SM4 & $26.5^{\circ} \mathrm{C}$ & $3.24 \mathrm{NTU}$ & $\begin{array}{c}12.5 \mathrm{~m} \\
\mathrm{~g} / \mathrm{L}\end{array}$ & 7.44 & $\begin{array}{c}3.5 \\
\mathrm{mg} / \mathrm{L}\end{array}$ & $\begin{array}{r}5.24 \\
\mathrm{mg} / \mathrm{L}\end{array}$ & $\begin{array}{c}1.3 \\
\mathrm{mg} / \mathrm{L}\end{array}$ & $\begin{array}{c}\text { Kelas II, III } \\
\text { dan IV }\end{array}$ \\
\hline
\end{tabular}

Sumber : BARISTAND Banda Aceh, 2017

\section{Spektrum Transmisi LPAS Kualitas Air Sumur}

Deteksi kualitas air sumur masyarakat dan sumur TPA Gampong Jawa menggunakan rentang panjang gelombang $4000-10.000 \mathrm{~cm}^{-1}$.dimana terlihat seperti Gambar 6 .

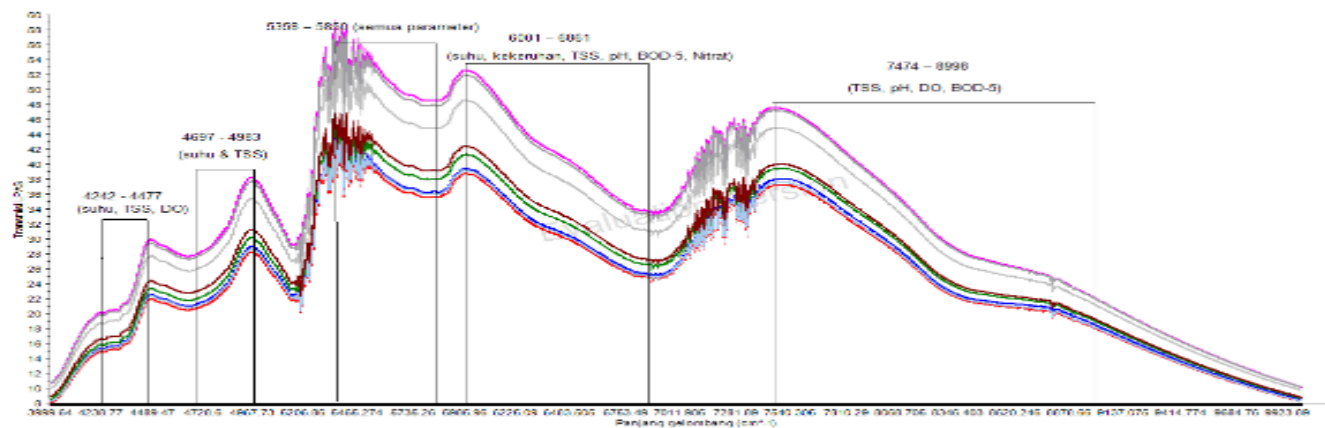

Gambar 1. Spektrum transmisi LPAS dari sampel air

Gambar tersebut menunjukkan letak masing - masing parameter sampel air pada rentang panjang gelombang tertentu. Spektrum transmisi untuk sampel air ini dapat terjadi akibat adanya perubahan vibrasi energi dalam bentuk overtone, widging dan twisting. Spektrum LPAS ini berbasis elektro-optik sehingga termasuk salah satu metode yang tidak merusak bahan (non-destructive method).

Deteksi Kualitas Air Sumur Masyarakat Akibat Penumpukan Limbah di Sekitar

Tempat Pembuangan Akhir Menggunakan Laser Photo-Acoustics Spectroscopy

di Gampong Jawa Kecamatan Kuta Raja Banda Aceh

(Khairul Abdi Ruslana, Ichwana, Agus Arip Munawar*)

JIMFP(TEP) November, 2018, Vol. 3 No. 4: 869-878 
Terlihat bahwasanya pada panjang gelombang tertentu terdapat beberapa parameter yang terdeteksi. Parameter suhu terdeteksi pada panjang gelombang $4242-4477 \mathrm{~cm}-1,4697-4983 \mathrm{~cm}-1$, 5358 - $5850 \mathrm{~cm}-1$ dan $6001-6861 \mathrm{~cm}-1$. Kemudian parameter kekeruhan terdapat pada panjang gelombang $5358-5850 \mathrm{~cm}-1$ dan $6001-6861 \mathrm{~cm}-1$. Parameter TSS terdapat pada panjang gelombang 4242 - $4477 \mathrm{~cm}-1,4697$ - $4983 \mathrm{~cm}-1,5358$ - $5850 \mathrm{~cm}-1,6001-6861 \mathrm{~cm}-1$ dan $7474-8998 \mathrm{~cm}-1$. Lalu parameter $\mathrm{pH}$ terletak pada rentang panjang gelombang $5358-5850 \mathrm{~cm}-1,6001-6861 \mathrm{~cm}-1$ dan $7474-8998 \mathrm{~cm}-1$. Parameter DO terdapat pada rentang panjang gelombang $4242-4477 \mathrm{~cm}-1,5358-$ $5850 \mathrm{~cm}-1$ dan $7474-8998 \mathrm{~cm}-1$. Parameter BOD-5 terdapat pada panjang gelombang $5358-5850$ $\mathrm{cm}-1,6001-6861 \mathrm{~cm}-1$ dan $7474-8998 \mathrm{~cm}-1$. Parameter nitrat (NO3-) terdapat pada rentang panjang gelombang $5358-5850 \mathrm{~cm}-1$ dan $6001-6861 \mathrm{~cm}-1$.

Spektrum yang dihasilkan terkadang mengalami beberapa gangguan (noise) dimana gangguan ini dihasilkan dari beberapa hal diantaranya suhu sensor yang terlalu panas (overheat), cahaya mengenai objek lain seperti udara, perubahan curvature dari integrating sphere dan penguatan optik yang berlebihan (Nicolai et al., 2007). Karena itu, perlu dilakukan perbaikan spektrum guna menghasilkan spektrum yang lebih baik dan akurat. Pada penelitian ini metode koreksi spektrum yang digunakan ialah peak normalization dan cutting edge filtering. Metode koreksi ini mampu menghilangkan interference, light scattering dan perubahan jarak cahaya.

Kemudian data spektrum akan dikoreksi oleh metode koreksi peak normalization sehingga bentuk spektrum akan berubah seperti pada Gambar 7.

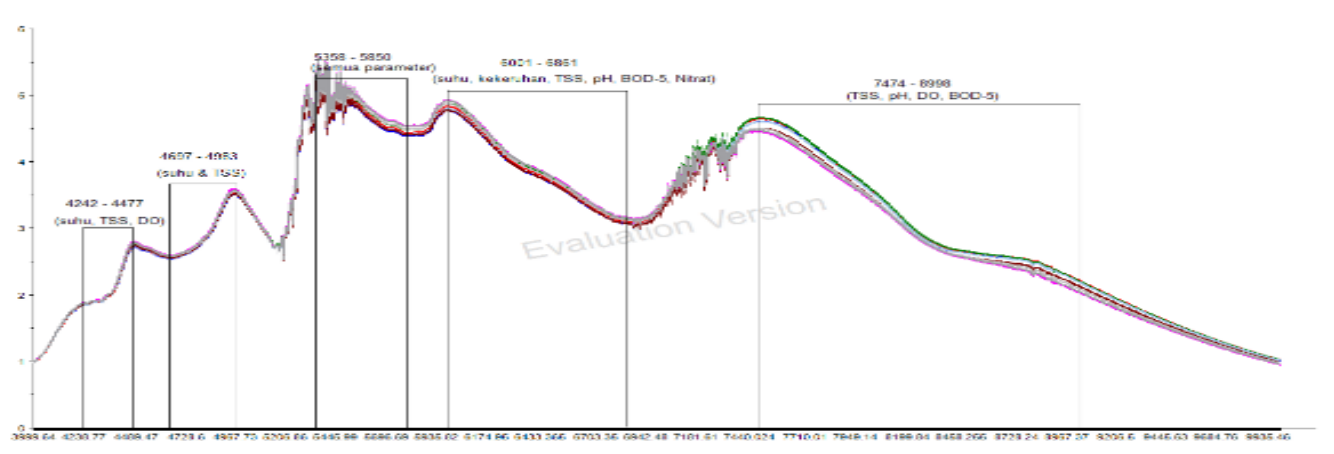

Gambar 2. Spektrum transmisi LPAS dari sampel air menggunakan peak normalization

Setelah dilakukan koreksi menggunakan metode koreksi peak normalization, maka selanjutnya dilakukan koreksi dengan menggunakan metode koreksi cutting edge filtering. Metode cutting edge filtering berfungsi untuk memotong batasan pada spektrum sehingga dapat memberikan batasan data pada spektrum. Hasil koreksi spektrum transmisi LPAS menggunakan metode cutting edge filtering dapat dilihat pada Gambar 8 .

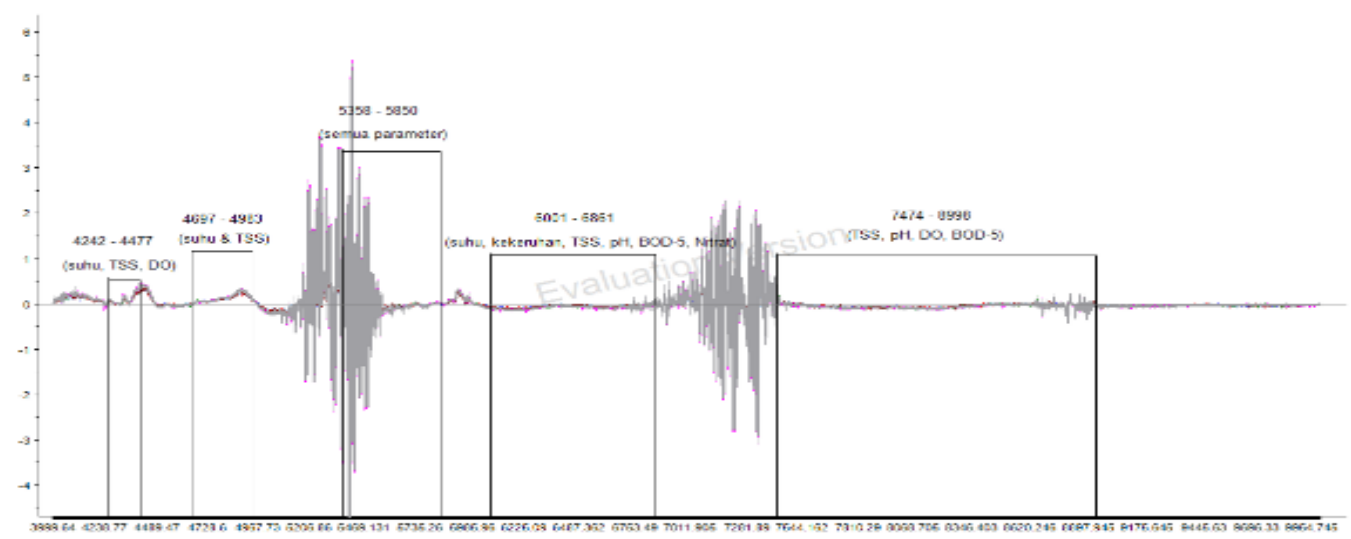

Gambar 3. Spektrum transmisi LPAS dari sampel air menggunakan cutting edge filtering

Deteksi Kualitas Air Sumur Masyarakat Akibat Penumpukan Limbah di Sekitar

Tempat Pembuangan Akhir Menggunakan Laser Photo-Acoustics Spectroscopy

di Gampong Jawa Kecamatan Kuta Raja Banda Aceh

(Khairul Abdi Ruslana, Ichwana, Agus Arip Munawar*)

JIMFP(TEP) November, 2018, Vol. 3 No. 4: 869-878 


\section{Panjang Gelombang Relevan Untuk Prediksi Parameter Air Sumur}

Panjang gelombang relevan untuk prediksi masing - masing parameter air sumur dilakukan untuk menduga keberadaan parameter - parameter air sumur pada setiap rentang panjang gelombang tertentu. Rentang panjang gelombang yang digunakan ialah $4000-10000 \mathrm{~cm}^{-1}$. Masing - masing parameter air sumur memiliki grafik gelombang yang berbeda - beda sehingga parameter - parameter tersebut terletak pada rentang panjang gelombang yang berbeda. Grafik gelombang masing - masing parameter dihasilkan setelah menerapkan metode regresi yakni PLSR (Partial Least Square Regression) dan metode koreksi peak normalization atau metode koreksi cutting edge filtering. Setelah itu keberadaan masing - masing parameter kualitas air ditentukan pada tiap - tiap puncak gelombang dan lembah gelombang.

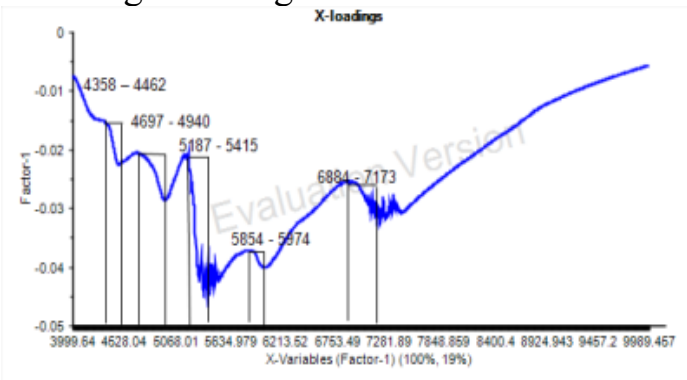

Gambar 4. Loading plot deteksi suhu

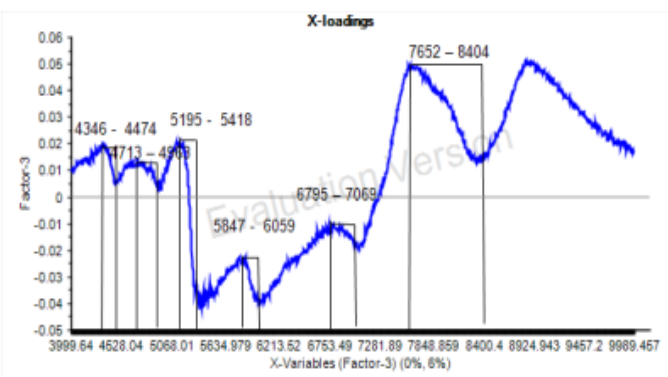

Gambar 6. Loading plot deteksi TSS

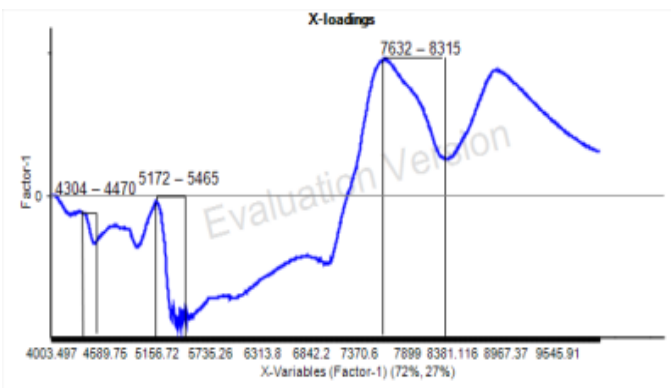

Gambar 8. Loading plot deteksi DO

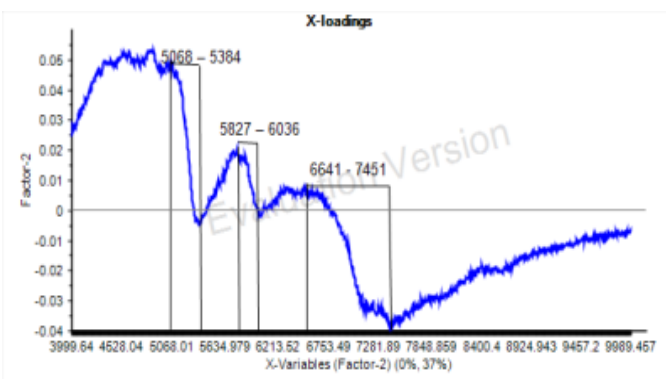

Gambar 5. Loading plot deteksi kekeruhan

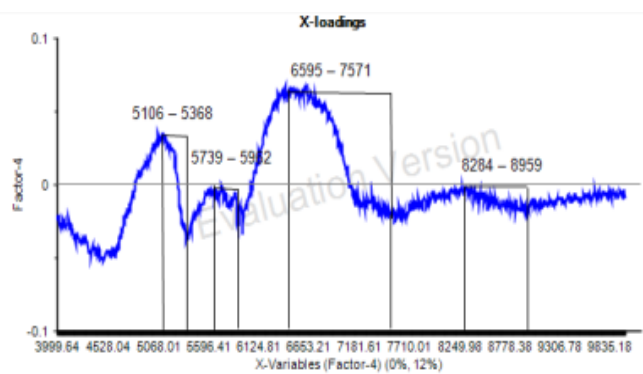

Gambar 7. Loading plot deteksi pH

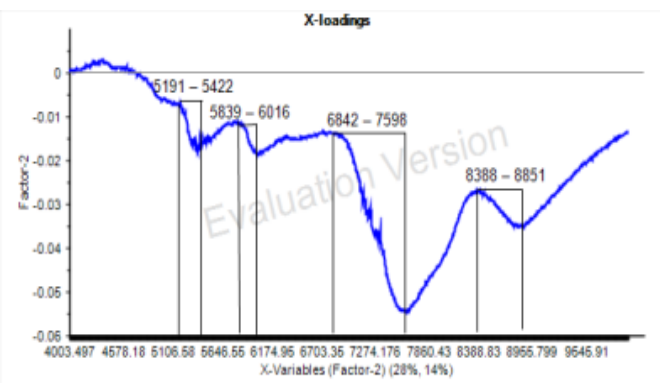

Gambar 9. Loading plot deteksi BOD-5

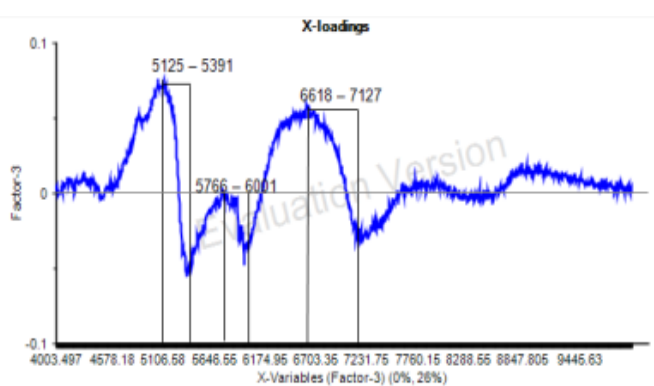

Gambar 10. Loading plot deteksi Nitrat $\left(\mathrm{NO}_{3}-\right)$

Deteksi Kualitas Air Sumur Masyarakat Akibat Penumpukan Limbah di Sekitar

Tempat Pembuangan Akhir Menggunakan Laser Photo-Acoustics Spectroscopy

di Gampong Jawa Kecamatan Kuta Raja Banda Aceh

(Khairul Abdi Ruslana, Ichwana, Agus Arip Munawar*)

JIMFP(TEP) November, 2018, Vol. 3 No. 4: 869-878 


\section{Prediksi Kualitas Air Berbasis Spektrum LPAS}

Tabel 6. Data Hasil Kalibrasi Raw Spektrum Untuk Prediksi Kualitas Air.

\begin{tabular}{cccccc}
\hline Parameter & RMSEC & SD & RPD & $\mathrm{R}^{2}$ & $\mathrm{r}$ \\
\hline Suhu & 0.04 & 0.09 & 1.94 & 0.69 & 0.83 \\
Kekeruhan & 1.95 & 8.36 & 4.28 & 0.93 & 0.96 \\
$\mathrm{TSS}$ & 3.75 & 33.24 & 8.86 & 0.98 & 0.99 \\
$\mathrm{pH}$ & 0.05 & 0.25 & 4.80 & 0.95 & 0.97 \\
BOD-5 & 0.37 & 2.18 & 5.78 & 0.83 & 0.91 \\
DO & 0.26 & 0.98 & 3.73 & 0.98 & 0.99 \\
Nitrat $\left(\mathrm{NO}_{3^{-}}\right)$ & 0.03 & 0.26 & 6.94 & 0.97 & 0.98 \\
\hline
\end{tabular}

Tabel 7. Data Hasil Kalibrasi Menggunakan Metode Koreksi Peak Normalization Untuk Prediksi Kualitas Air.

\begin{tabular}{cccccc}
\hline Parameter & RMSEC & SD & RPD & $\mathrm{R}^{2}$ & $\mathrm{r}$ \\
\hline Suhu & 0.04 & 0.09 & 1.83 & 0.65 & 0.81 \\
Kekeruhan & 1.39 & 8.36 & 6.00 & 0.96 & 0.98 \\
TSS & 5.70 & 33.24 & 5.82 & 0.96 & 0.98 \\
pH & 0.06 & 0.25 & 3.94 & 0.92 & 0.96 \\
BOD-5 & 0.32 & 2.18 & 6.66 & 0.87 & 0.93 \\
DO & 0.27 & 0.98 & 3.62 & 0.98 & 0.99 \\
Nitrat $\left(\mathrm{NO}_{3^{-}}\right)$ & 0.04 & 0.26 & 6.02 & 0.96 & 0.98 \\
\hline
\end{tabular}

Tabel 8. Data Hasil Kalibrasi Menggunakan Metode Koreksi Cutting Edge Filtering Untuk Prediksi Kualitas Air.

\begin{tabular}{cccccc}
\hline Parameter & RMSEC & SD & RPD & $\mathrm{R}^{2}$ & $\mathrm{r}$ \\
\hline Suhu & 0.04 & 0.09 & 2.22 & 0.76 & 0.88 \\
Kekeruhan & 0.98 & 8.36 & 8.52 & 0.98 & 0.99 \\
TSS & 1.93 & 33.24 & 17.20 & 0.99 & 0.99 \\
pH & 0.09 & 0.25 & 2.56 & 0.82 & 0.90 \\
BOD-5 & 0.37 & 2.18 & 5.88 & 0.83 & 0.91 \\
DO & 0.24 & 0.98 & 3.99 & 0.98 & 0.99 \\
Nitrat $\left(\mathrm{NO}_{3}-\right)$ & 0.04 & 0.26 & 6.57 & 0.97 & 0.98 \\
\hline
\end{tabular}

Deteksi Kualitas Air Sumur Masyarakat Akibat Penumpukan Limbah di Sekitar 


\section{KESIMPULAN DAN SARAN}

\section{Kesimpulan}

Berdasarkan hasil penelitian yang telah dilakukan maka dapat disimpulkan bahwasanya ; Aplikasi laser fotoakustik dapat mendeteksi kandungan parameter fisik air sumur seperti suhu, kekeruhan dan TSS serta parameter kimia air sumur seperti $\mathrm{pH}, \mathrm{DO}, \mathrm{BOD}-5$ dan Nitrat $\left(\mathrm{NO}_{3}{ }^{-}\right)$dengan menggunakan rentang panjang gelombang $4000-10000 \mathrm{~cm}^{-1}$. Metode koreksi spektrum yang paling baik digunakan untuk prediksi suhu, kekeruhan, TSS dan DO ialah metode koreksi cutting edge filtering, prediksi $\mathrm{pH}$ dan $\mathrm{NO}_{3}$ - paling baik menggunakan data raw spektrum sementara prediksi BOD-5 paling baik mengggunakan metode koreksi peak normalization. Data raw spektrum nilai r berkisar pada 0.83 0.99 , nilai RMSEC berkisar pada 0.03 - 3.75, nilai $\mathrm{R}^{2} 0.69$ - 0.98, nilai RPD 1.94 - 6.94. Metode koreksi peak normalization memiliki nilai $\mathrm{r}$ berkisar pada 0.81 - 0.99, nilai RMSEC 0.044- 5.70, nilai $\mathrm{R}^{2} 0.65$ 0.98, nilai RPD 1.83 - 6.66. Metode koreksi cutting edge filtering memiliki nilai $\mathrm{r}$ berkisar 0.88 - 0.99 , nilai RMSEC 0.04 - 1.93, nilai $\mathrm{R}^{2} 0.76$ - 0.99, nilai RPD 2.22 - 17.20. Metode regresi PLSR (Partial Least Square Regression) dapat diterapkan pada aplikasi laser fotoakustik dalam mendeteksi kandungan parameter suhu, kekeruhan, TSS, $\mathrm{pH}, \mathrm{DO}, \mathrm{BOD}-5$ dan Nitrat $\left(\mathrm{NO}_{3}^{-}\right)$pada air sumur.

\section{Saran}

Saran yang dapat penulis berikan pada penelitian berikutnya ialah perlu dilakukan penelitian lebih lanjut dengan mendeteksi parameter - parameter lain seperti Fosfat, Daya Hantar Listrik, Total Padatan Terlarut (TPT) dan salinitas pada sampel air. Perlu pula diterapkan metode regresi linear seperti metode SVMR (Support Vector Machine Regression), PCA (Principal Component Analysis) maupun metode regresi non linear.

\section{DAFTAR PUSTAKA}

Karoui R., A, M. Mouazena, E. Dufourb, L. Pilllonelc, E. Schallerd, J. De Baerdamaekera, dan J.O. Bossetc. 2006. Chemical characterisation of european emmental cheese by Near Infrared Spectroscopy using chemometric tools. International Dairy Journal. 16: 1211-1217.

Munawar, A.A., Yusmanizar, Syah, H. 2016. Rapid and simultaneous detection of honey adulteration and quality attributes prediction using Near Infrared Spectroscopy. AIC-ICMSA conference, 46 October 2016.

Nicolai, B.M., K. Buellens, E. Bobelyn, A. Peirs, W. Saeys, K.I. Theron, dan J. Lamertyn. (2007). Nondestructive measurement of fruit and vegetable quality by means of NIR spectroscopy : A review. Postharvest Biology and Technology, 46, 99-118.

Ulva, M. C. 2016. Prediksi Kadar Air Bubuk Biji Kakao Menggunakan NIRS Dengan Metode PLS (Dengan Pre-Treatment Derivative ke-1 dan Mean Centering). Skripsi Jurusan Teknik Pertanian. Universitas Syiah Kuala. Banda Aceh, Indonesia.

Wasono, M.A.J. 1998. Konstruksi dan Kinerja Spektrometer Fotoakustik Laser $\mathrm{CO}_{2}$ Untuk Memonitor Emisi Etilen Dalam Metabolisme Buah Tripis Pasca Panen. Disertasi. Pascasarjana UGM, Yogyakarta.

Zulfahrizal, A. A. Munawar, dan H. Meilina. 2015. Rancang bangun Alat Sensor Portable Berbasis Pengembangan Aplikasi Teknologi Near InfraRed Sebagai Metode Baru yang Rapid dan Non Destructive untuk prediksi Kualitas Kakao. Laporan Penelitian. Universitas Syiah Kuala, Banda Aceh. 